\title{
Apical adaptation, sealing ability and push-out bond strength of five root-end filling materials
}

\begin{abstract}
Pablo Andrés AMOROSO-SILVA Marina Angélica MARCIANO Bruno Martini GUIMARÃES Marco Antonio Hungaro DUARTE Ana Flavia SANSON Ivaldo Gomes de MORAES
\end{abstract}

Operative Dentistry, Endodontics and Dental Materials, School of Dentistry, Universidade de São Paulo - USP, Bauru, SP, Brazil.

Declaration of Interests: The authors certify that they have no commercial or associative interest that represents a conflict of interest in connection with the manuscript.

Corresponding Author:

Pablo Andrés Amoroso Silva

E-mail: pabloamoroso@usp.br

DOI: 10.1590/1807-3107BOR-2014.vol28.0043 Epub XXXXX, 2014

Submitted: Feb 25, 2014

Accepted for publication: Jun 01, 2014

Last revision: Aug 08, 2014
ABSTRACT: This study compared the fluid filtration, adaptation to the root canal walls, and the push-out bond strength of two resin-based sealers and three calcium silicate-based retrograde filling materials. Fifty maxillary canines were shaped using manual instruments and the apical portion was sectioned. Retrograde cavities of 3-mm depth were prepared. The specimens were divided into five groups $(n=10)$ : Sealer 26 (S26); MBPc (experimental); MTA; Portland cement with 20\% zirconium oxide (PC/ZO), and Portland cement with $20 \%$ calcium tungstate (PC/CT). The fluid filtration was measured at 7 and 15 days. To evaluate the interfacial adaptation, sections of the teeth, 1 and $2 \mathrm{~mm}$ from the apex, were prepared and the percentage of gaps was calculated. The push-out bond strength at $2 \mathrm{~mm}$ from the apex was evaluated. Statistical analysis was performed using the ANOVA/Tukey's test $(\mathrm{p}<0.05)$. At 7 and 15 days $(\mathrm{p}=0.0048, \mathrm{p}=0.006)$, the PC/CT group showed higher fluid filtration values when compared to other groups. At $1 \mathrm{~mm}$ from the apex, no statistical differences in the adaptation were found among the cements $(\mathrm{p}=0.44)$. At $2 \mathrm{~mm}$ from the apex, the PC/ZO group presented statistically lower percentage of gaps than S26, MBPc, and MTA ( $p=0.0007)$. The MBPc group showed higher push-out bond strength than other cements evaluated $(p=0.0008)$. The fluid filtration and interfacial adaptation of the calcium silicate-based cements were similar to those of the resin-based cements. The resinous cement MBPC showed superior push-out bond strength.

Keywords: Root Canal Filling Materials; Endodontics; Retrograde Obturation; Dental Leakage; Dental Bonding.

\section{Introduction}

Bacterial infection is widely known as the main cause of apical periodontitis, the amount of microorganisms in the infected area is a key factor determining the healing or persistence of the apical lesion. ${ }^{1}$ When conventional root canal treatment fails, apical surgery is recommended. This procedure requires the root-end resection, eliminating the contaminated portion of the root where the microorganisms are resistant to the disinfection of the canal and are present in form of a biofilm. ${ }^{2}$

The selection and use of appropriate root-end filling material that exhibits good adaptation and biological properties, while preventing the leakage is critical for the long-term success of the periapical surgery. ${ }^{3}$ 
An adequate root-end filling material should be able to prevent the infiltration of bacteria into the root canals. ${ }^{4}$ Gutta-percha, amalgam, calcium silicatebased cements, and MTA have been used as rootend filling materials. ${ }^{5,6}$ The MBPc was developed as a retrograde or root perforation-repair material and exhibits good sealing ability, marginal adaptability, physical, and biological properties. It is an epoxyresin-based sealer containing calcium hydroxide and is available in glass vials as a hydrophobic with a 4:1 base-to-catalyst ratio.?

Because the leakage from the apical or the coronal direction often leads to treatment failure, the fluid filtration test is frequently used to evaluate leakage. ${ }^{8}$ Marginal adaptation ${ }^{9}$ and bond strength of the material with the dentin are also essential factors for the success of the endodontic procedures..$^{10}$ The pushout test has been successfully used for measuring the dislocation resistance and the bond strength of a restorative material to dentin. The objective of the study was to compare the fluid filtration, adaptation to the root canal walls, and the push-out bond strength of two resin- and three calcium silicate-based retrograde filling materials. We tested the validity of the hypothesis that there is no difference in the filling quality of the tested retrograde filling materials.

\section{Methodology}

Fifty-four maxillary canines with straight root canals were selected following the approval of the ethics committee (CEP 191-2011). The teeth were sectioned using a 0.3-mm Isomet saw (Buehler, Lake Bluff, USA), leaving $15 \mathrm{~mm}$ of root length. The working length was established by taking a \#10 K file (DentsplyMaillefer, Ballaigues, Switzerland) until the apical foramen and then subtracting $1 \mathrm{~mm}$. The root canals were shaped in a crown-down manner to a \#45 K file (DentsplyMaillefer, Ballaigues, Switzerland). To irrigate the canal, $2.5 \%$ sodium hypochlorite was used. For smear layer removal, 17\% EDTA (Biodinâmica, Ibiporã, Brazil) was applied for $3 \mathrm{~min}$. After washing with $2 \mathrm{~mL}$ distilled water, the canals were dried using paper points. A 45/0.2 gutta-percha cone coated with AH Plus sealer (DentsplyMaillefer, Ballaigues, Switzerland) was inserted to the working length. The root canals were filled using the lat- eral compaction technique with the help of a B finger spreader (DentsplyMaillefer, Ballaigues, Switzerland) inserted $2 \mathrm{~mm}$ short of the working length and accessory gutta-percha points of the size 20/0.2. The teeth were stored at $100 \%$ humidity and $37^{\circ} \mathrm{C}$ for 24 $\mathrm{h}$ to allow the sealer to set. Following this, the teeth were horizontally sectioned at $2 \mathrm{~mm}$ from the apex and the root-end cavities were prepared using a 1012 bur (KG Sorensen, Barueri, Brazil) until a depth of $3 \mathrm{~mm}$. The cavities were irrigated with $2 \mathrm{~mL}$ of $17 \%$ EDTA (Biodinâmica, Ibiporã, Brazil) for 2 min to eliminate the smear layer, irrigated with $2 \mathrm{~mL}$ distilled water, and dried using paper points. The specimens were then divided into five groups $(n=10)$ according to the sealer used to obturate the root-end cavity: Sealer 26 (S26), (Dentsply, Petrópolis, Brazil), MBPc (experimental), MTA (Angelus, Londrina, Brazil), Portland cement (Votorantim-Cimentos, São Paulo, Brazil) with zirconium oxide (PC/ZO), and Portland cement with calcium tungstate (PC/CT). The S26 was manipulated to a dense consistency by applying a 5:1 powder to resin ratio. ${ }^{11}$ An accelerator to base ratio of 1:1 was used in the preparation of MBPc. MTA was prepared according to the manufacturer's instructions. In the Portland cement groups, $20 \%$ by weight of calcium tungstate or zirconium oxide was added. Samples were weighed using an analytical balance with a sensitivity of $0.0001 \mathrm{~g}$. The manipulation of the groups 4 and 5 was performed using a quantity of $1 \mathrm{~g}$ of powder and $0.4 \mathrm{~mL}$ of distilled water. After filling, the correct obturation was radiographically confirmed and the samples were maintained under an atmosphere of $100 \%$ humidity at $37^{\circ} \mathrm{C}$.

\section{Assessment of sealing ability}

The sealing ability of all groups was measured using a computerized fluid filtration-recording device (Flodec System; De Marco Engineering, Geneva, Switzerland). The fluid movement was monitored by following the movement of an air bubble with the help of a diode laser. This device transforms the linear displacement of an air-liquid meniscus inside the pipette into volume and flow data at a sampling rate of one measurement per second. ${ }^{12}$ After 7 days of storage, the root surfaces were waterproofed by applying two coats of nail varnish, except on the apex. 
The nail varnish was used to limit the passage of any fluid across the dentinal tubules and to insure that any fluid flow observed was caused by flow along the interface between the sealer and the dentin. Four extra teeth were used for control groups-positive (no filled canal) $(n=2)$ and negative (filled canal and completely covered with nail varnish) $(n=2)$.

To estimate the microleakage $\left(\mu \mathrm{L} / \mathrm{min}^{-1}\right)$, recordings were made for $12 \mathrm{~min}$ under $1.2 \mathrm{~atm}$ pressure for each tooth. These samples were incubated for 15 days, counting from the day of obturation, at $37^{\circ} \mathrm{C}$ in humidified atmosphere and the recordings were repeated.

\section{Interfacial adaptation}

Following the fluid filtration test, the samples were horizontally sectioned at 1 and $2 \mathrm{~mm}$ from the apex using a 0.3-mm Isomet saw and polished using sandpaper (Politriz, Arotec, Cotia, Brazil) under continuous water irrigation. To calculate the percentage of voids between radicular dentin and the retrograde material $\left(\mathrm{mm}^{2}\right)$, the area of the image of the canal and that of the visible voids were measured using a stereomicroscope under $50 \times$ magnification (Stemi 2000C; Carl Zeiss, Jena, Germany) and Axiovision software (Carl Zeiss, Jena, Germany).

\section{Push-out bond strength}

The 2-mm cross sections were positioned on a metal base with a hold that was centered with the root canal. The aligned device was subjected to a vertical force with the help of a metal tip of 1-mm diameter, fixed to a universal testing machine (EMIC model DL 500 DF, No. 5775, Curitiba, Brazil). The maximal force applied to the cement before the displacement was measured in Newtons (N). The push-out value, expressed in $\mathrm{MPa}$, was calculated by dividing the force in $\mathrm{N}$ by the area of the root canal in $\mathrm{mm}^{2}$. To determine the mode of failure, the specimens were examined under a stereomicroscope (Stemi 2000C; Carl Zeiss, Jena, Germany) at $20 \times$ magnification.

\section{Statistical analysis}

Statistical analysis was performed using the ANOVA/Tukey's tests because a normal distribution was observed in the D'Agostino \& Pearson test. The Prism 5.0 software (GraphPad Software Inc., La Jolla, USA) was used as the analytical tool and the significance level was set at $5 \%$.

\section{Results}

\section{Fluid filtration}

The mean and standard deviation of fluid penetration $\left(\mu \mathrm{L} / \mathrm{min}^{-1}\right)$ are shown in Table 1 . At 7 days, there was no statistically significant difference between the retrograde filler groups $(p=0.0048)$. The PC/CT group showed higher microleakage than other groups $(p=0.0048)$. During the 15-day period of monitoring, the MTA group showed higher microleakage than MBPc group $(p=0.006)$ and the $P C / Z O$ group showed higher fluid infiltration than the MBPc group $(p=0.006)$.

\section{Voids between radicular dentin and retrograde material}

The median and the range of the percentages of gaps obtained from the stereomicroscopy analysis of the root-end fillings at 1 and $2 \mathrm{~mm}$ from the apex are shown in Table 1 . At $1 \mathrm{~mm}$ from the apex, no significant differences in the adaptation were observed between the tested materials $(p=$ 0.44). At $2 \mathrm{~mm}$ from the apex, the MTA, PC/ZO, and the PC/CT groups showed a higher percentage of voids $(p=0.0007)$. The lowest mean value was observed for the PC/ZO group.

Table 1. The mean and standard deviation of fluid filtration rate $(\mu \mathrm{L} / \mathrm{min}-1)$ and the percentages of gaps in the root-end fillings at 1 and $2 \mathrm{~mm}$ from the apex. Different letter in each column indicate statistically significant differences $(p<0.05)$

\begin{tabular}{ccccc}
\hline Group & Fluid filtration 7 days & Fluid filtration 15 days & Gap 1 mm & Gap $2 \mathrm{~mm}$ \\
S26 & $0.02^{a} \pm 0.01$ & $0.03^{\mathrm{ab}} \pm 0.01$ & $4.31^{\mathrm{a}} \pm 2.73$ & $7.88^{\mathrm{ab}} \pm 2.62$ \\
MBPC & $0.02^{\mathrm{a}} \pm 0.00$ & $0.01^{\mathrm{a}} \pm 0.00$ & $4.66^{\mathrm{a}} \pm 3.69$ & $7.83^{\mathrm{ab}} \pm 4.77$ \\
MTA & $0.03^{\mathrm{a}} \pm 0.01$ & $0.05^{\mathrm{b}} \pm 0.02$ & $6.72^{\mathrm{a}} \pm 3.74$ & $9.84^{\mathrm{a}} \pm 4.84$ \\
PC/ZO & $0.02^{\mathrm{a}} \pm 0.01$ & $0.03^{\mathrm{ab}} \pm 0.02$ & $4.59^{\mathrm{a}} \pm 2.35$ & $3.08^{\mathrm{c}} \pm 2.42$ \\
PC/CT & $0.08^{\mathrm{b}} \pm 0.08$ & $0.06^{\mathrm{b}} \pm 0.04$ & $6.19^{\mathrm{a}} \pm 4.57$ & $4.65^{\mathrm{bc}} \pm 2.24$ \\
\hline
\end{tabular}




\section{Push-out bond strength}

Graphic output of the push-out strength (MPa) test for each group is shown in Figure 1. The MBPc showed higher push-out bond strength $(42.93 \pm 18.18$ Mpa) than other evaluated cements $(p=0.0008)$, while PC/CT produced the lowest push-out values $(17.73 \pm 9.83)(p=0.0008)$. The S26 showed $24.80 \pm$ 10.60 Mpa push-out strength, which was similar in magnitude to that produced by MTA $(25.35 \pm 9.44)$ and PC/ZO (23.15 \pm 11.65$)$ cements.

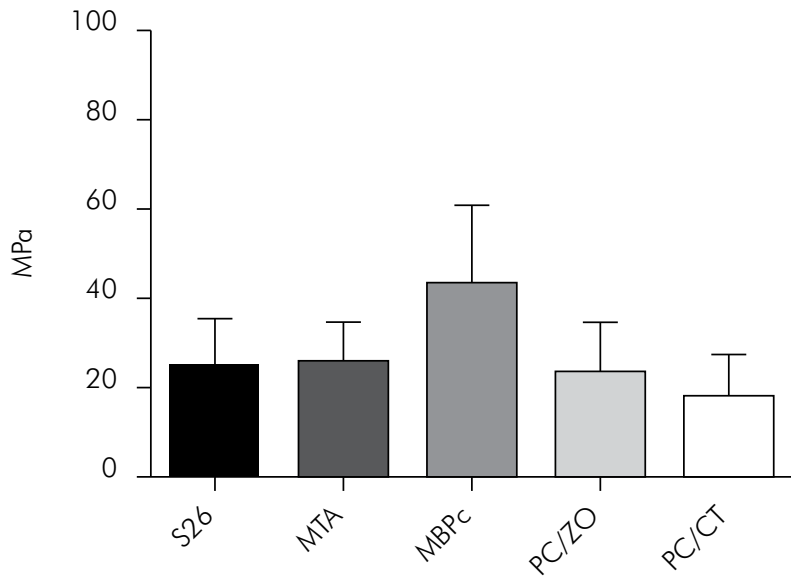

Figure 1. Graphical representation of the mean and standard deviation of the push-out strength (MPa).

\section{Discussion}

The selection of appropriate retrograde filling material is critical for insuring favorable outcome of endodontic surgery. Using models that simulate the clinical conditions, a number of studies have attempted to assess the physical, chemical, and biological properties of these filling materials. ${ }^{13,14,15} \mathrm{In}$ the present study, we found significant differences between the performance of various retrograde filling materials tested, Thus, our results contradict the expectations of the null hypothesis.

Dye penetration techniques and radioisotopes have been used in the analysis of microleakage around the filling materials. ${ }^{16,17}$ The fluid filtration method, offers the unique opportunity to repeat the analyses on the same specimen. ${ }^{18}$ In our study the materials analyzed failed to prevent the infiltration of fluids into the root-end filled cavities. A previous study ${ }^{19}$ found low values of infiltration when using the MBPc and $\mathrm{AH}$ Plus resinous sealers than when MTA was used. A separate study that assessed the apical leakage found that MBPc had superior sealing ability as a root-end filling material when compared to MTA and CPM. ${ }^{16}$ The presence of resin component in the formulation of MBPc and S26 likely improved the sealing by the root-end filling due to enhanced adhesion to the dentinal walls and lower contraction. In our study the MBPc, S26, MTA, and $\mathrm{PC} / \mathrm{ZO}$ also showed low values of fluid infiltration when measured on days 7 and 15. In comparison, the PC/CT group showed high values of infiltration. The Portland cement lacks sufficient radiopacity to be distinguished radiographically from the adjacent anatomic structures such as dental tissues and bone. In the present study, zirconium oxide and calcium tungstate were added as radiopacifiers to the calcium silicate cement. These radiopacifiers are present in the AH Plus and promote the radiopacity of the material. Studies have revealed that Portland cement containing zirconium oxide and calcium tungstate show improved physicochemical properties such as solubility, setting time, promotion of an alkaline $\mathrm{pH}$, and good calcium ion release. ${ }^{20}$ Further, these materials also showed reduced cytotoxicity, enabling their clinical applications. ${ }^{21}$ In the present study, MTA showed no statistically significant difference from PC when zirconium oxide was included in its composition. However, addition of calcium tungstate led to significantly higher fluid infiltration both at day $7(p=0.0048)$ and $15(p=0.0006)$ than when other materials were used. These results suggest that the increased fluid infiltration was likely due the addition of radiopacifiers to the PC composition. The calcium tungstate likely altered the structure of the PC, causing the formation of cracks and leading to increased infiltration. Further evaluation of the physico-chemical properties of these materials may reveal the factors that contributed to the increased fluid infiltration rates.

The results of the microscopic examination showed that there was no direct relationship between the percentage of voids and the apical leakage. One possibility is that the voids observed at 1 and $2 \mathrm{~mm}$ from 
the apex may not be sufficient to allow the fluid infiltration. The voids observed at $1 \mathrm{~mm}$ from the apex may not correspond to those observed at $2 \mathrm{~mm}$ from the apex, blocking the continuity of the fluids in the obturation. In contrast to the properties of the resinous material, the MTA flows less freely, enabling the manipulation and insertion into the root canal a more challenging procedure. This may explain the high percentage of voids observed at the sections obtained at 1 and $2 \mathrm{~mm}$ from the apex. However, during apicoectomy, the clinician has a better control while placing the retrograde filling, particularly when sealing the external part of the root-end section. It is critical that the external surface of the material is well adapted, because this portion remains in contact with the periapical tissues. The retrograde filling materials should also resist dislodging forces and solubility of the material. ${ }^{22}$ Our study revealed that the resin-based cement MBPc had greater bond strength than other materials tested. The volumetric expansion of the resinous materials, ${ }^{23}$ the covalent bond between the amino group and the epoxy resin components, ${ }^{24}$ and the sealer penetration inside the dentinal tubules ${ }^{25}$ may favor high bond strength between the material and the root canal walls. ${ }^{26} \mathrm{How}$ ever, we found that the groups with less voids had greater fluid infiltration. Our results are consistent with those of a previous study, which found no significant correlation between sealer penetration into the dentinal tubules and the sealing quality. ${ }^{27}$

MTA exhibited better mechanical properties than PC. When these materials encounter the oral fluids, precipitation of carbonated apatite is initiated, which leads to mineral nucleation on dentin, forming an

\section{References}

1. Siqueira Jr JF, Rocas IN. Clinical implications and microbiology of bacterial persistence after treatment procedures. J Endod. 2008 Nov;34(11):1291-301.

2. Noiri Y, Ehara A, Kawahara T, Takemura N, Ebisu S. Participation of bacterial biofilms in refractory and chronic periapical periodontitis. J Endod. 2002 Oct;28(10):679-83.

3. Abdal AK, Retief DH. The apical seal via the retrosurgical approach. I.A. preliminary study. Oral Surg Oral Med Oral Pathol. 1982 Jun;53(6):614-21. interfacial layer with tag-like structures, and causing micromechanical retention to the dentin. However, the hardness of these materials and their retention to the dentinal walls depend on the water/powder ratio, temperature, humidity, the quantity of air trapped in the mixture, and the particle size of the materials. ${ }^{28}$ Higher particle size may affect the marginal adaptation to dentin. In contrast, the resinous materials chemically adhere to the root canal walls. The enhanced adhesion of the MBPc group as observed during the push-out test could be attributed to the ricinus communis polymer, which has been reported to have shown expansion. ${ }^{29}$ Further, the addition of calcium tungstate, but not zirconium oxide, affected the bond strength to the dentinal walls.

Although the results of this in vitro study showed better performance of the resin-based cements, other clinical factors, such as the presence of blood and other fluids during surgical procedures, may alter the physical properties of these materials and reduce the sealing ability as well as bond strength. In addition, MTA and PC show bioactivity and osteoconductivity, which are desirable properties when performing apical surgery procedures.

\section{Conclusions}

The calcium silicate-based cements showed similar fluid filtration and interfacial adaptation. The resinous cement MBPc showed superior push-out bond strength.

\section{Acknowledgments}

This work was supported by the Fundação de Amparo à Pesquisa do Estado de São Paulo (FAPESP 2011/19816-5). The authors declare that no conflict of interests exists.

\footnotetext{
4. Silva-Neto U, Moraes I. Capacidade seladora proporcionada por alguns materiais quando utilizados em perfurações na região de furca de molares humanos extraídos. J Appl Oral Sci. 2003 Mar;11(1):27-33.

5. Estrela C, Estrada-Bernabe PF, Almeida-Decurcio D, Almeida-Silva J, Rodrigues-Araujo-Estrela CA, Poli-Figueiredo JA. Microbial leakage of MTA, Portland cement, Sealapex and zinc oxide-eugenol as root-end filling materials. Med Oral Patol Oral Cir Bucal. 2011 May;16(3):418-24.
} 
6. Maltezos C, Glickman GN, Ezzo P, He J. Comparison of the sealing of Resilon, Pro Root MTA, and Super-EBA as rootend filling materials: a bacterial leakage study. J Endod. 2006 Apr;32(4):324-7.

7. Orosco FA, Bramante CM, Garcia RB, Bernardineli N, Moraes IG. Sealing ability of gray MTA Angelus (TM), CPM (TM) and MBPC used as apical plugs. J Appl Oral Sci. 2008 Feb;16(1):50-4.

8. Camps J, Pashley D. Reliability of the dye penetration studies. J Endod. 2003 Sep;29(9):592-4.

9. Reyes-Carmona JF, Felippe MS, Felippe WT. The biomineralization ability of mineral trioxide aggregate and Portland cement on dentin enhances the push-out strength. J Endod. 2010 Feb;36(2):286-91.

10. Wennberg A, Orstavik D. Adhesion of root canal sealers to bovine dentine and gutta-percha. Int Endod J. 1990 Jan;23(1):13-9.

11. Tanomaru-Filho M, Luis MR, Leonardo MR, Tanomaru JM, Silva LA. Evaluation of periapical repair following retrograde filling with different root-end filling materials in dog teeth with periapical lesions. Oral Surg Oral Med Oral Pathol Oral Radiol Endod. 2006 Jul;102(1):127-32.

12. Bouillaguet S, Shaw L, Barthelemy J, Krejci I, Wataha JC. Long-term sealing ability of Pulp Canal Sealer, AH-Plus, GuttaFlow and Epiphany. Int Endod J. 2008 Mar;41(3):219-26.

13. Torabinejad M, Hong CU, McDonald F, Pitt Ford TR. Physical and chemical properties of a new root-end filling material. J Endod. 1995 Jul;21(7):349-53.

14. Shipper G, Trope M. In vitro microbial leakage of endodontically treated teeth using new and standard obturation techniques. J Endod. 2004 Mar;30(3):154-8.

15. Leonardo MR, Salgado AA, Silva LA, Tanomaru Filho M. Apical and periapical repair of dogs' teeth with periapical lesions after endodontic treatment with different root canal sealers. Pesqui Odontol Bras. 2003 Jan-Mar;17(1):69-74.

16. Orosco FA, Bramante CM, Garcia RB, Bernardineli N, Moraes IG. Sealing ability, marginal adaptation and their correlation using three root-end filling materials as apical plugs. J Appl Oral Sci. 2010 Mar-Apr;18(2):127-34

17. Siqueira Jr JF, Rocas IN, Abad EC, Castro AJR, Gahyva SM, Favieri A. Ability of three root-end filling materials to prevent bacterial leakage. J Endod. 2001 Nov;27(11):673-5.

18. Martin RL, Monticelli F, Brackett WW, Loushine RJ, Rockman RA, Ferrari M, et al. Sealing properties of mineral trioxide aggregate orthograde apical plugs and root fillings in an in vitro apexification model. J Endod. 2007 Mar;33(3):272-5.
19. Vasconcelos BC, Bernardes RA, Duarte MA, Bramante CM, Moraes IG. Apical sealing of root canal fillings performed with five different endodontic sealers: analysis by fluid filtration. J Appl Oral Sci. 2011 Aug;19(4):324-8.

20. Hungaro Duarte MA, Minotti PG, Rodrigues CT, Zapata RO, Bramante CM, Tanomaru Filho M, et al. Effect of different radiopacifying agents on the physicochemical properties of white Portland cement and white mineral trioxide aggregate. J Endod. 2012 Mar;38(3):394-7.

21. Gomes Cornelio AL, Salles LP, Campos da Paz M, Cirelli JA, Guerreiro-Tanomaru JM, Tanomaru Filho M. Cytotoxicity of Portland cement with different radiopacifying agents: a cell death study. J Endod. 2011 Feb;37(2):203-10.

22. Torabinejad M, Higa RK, McKendry DJ, Pitt Ford TR. Dye leakage of four root end filling materials: effects of blood contamination. J Endod. 1994 Apr;20(4):159-63.

23. Orstavik D, Nordahl I, Tibballs JE. Dimensional change following setting of root canal sealer materials. Dent Mater. 2001 Nov;17(6):512-9.

24. Fisher MA, Berzins DW, Bahcall JK. An in vitro comparison of bond strength of various obturation materials to root canal dentin using a push-out test design. J Endod. 2007 Jul;33(7):856-8.

25. Haragushiku GA, Sousa-Neto MD, Silva-Sousa YT, Alfredo E, Silva SC, Silva RG. Adhesion of endodontic sealers to human root dentine submitted to different surface treatments. Photomed Laser Surg. 2010 Jun;28(3):405-10.

26. Ordinola-Zapata R, Bramante CM, Graeff MS, del Carpio Perochena A, Vivan RR, Camargo EJ, et al. Depth and percentage of penetration of endodontic sealers into dentinal tubules after root canal obturation using a lateral compaction technique: a confocal laser scanning microscopy study. Oral Surg Oral Med Oral Pathol Oral Radiol Endod. 2009 Sep;108(3):450-7.

27. De-Deus G, Brandao MC, Leal F, Reis C, Souza EM, Luna AS, et al. Lack of correlation between sealer penetration into dentinal tubules and sealability in nonbonded root fillings. Int Endod J. 2012 Jul;45(7):642-51.

28. Torabinejad M, Watson TF, Pitt Ford TR. Sealing ability of a mineral trioxide aggregate when used as a root end filling material. J Endod. 1993 Dec;19(12):591-5.

29. Pinheiro C, Guinesi A, de Camargo E, Pizzolitto A, Bonetti Filho I. Bacterial leakage evaluation of root canals filled with different endodontic sealers. Oral Surg Oral Med Oral Pathol Oral Radiol Endod. 2009 Dec;108(6):56-60. 